\title{
Wpływ sektora ICT na lukę produktywności między Unią Europejską i USA - analiza dla okresu 1996-2017
}

Impact of the ICT sector on the EU-US productivity gap analysis for the period 1996-2017

\section{Wprowadzenie}

Technologie informacyjno-komunikacyjne (ang. information and communication technologies - ICT) już od kilku dekad stanowią nieodłączny element życia gospodarczego poszczególnych krajów i gospodarki światowej jako całości. Definiuje się je jako „rodzinę technologii przetwarzających, gromadzących i przesyłających informacje w formie elektronicznej" (GUS, 2015). Wszelka działalność związana $\mathrm{z}$ tego typu technologiami odbywa się w ramach sektora ICT obejmującego produkcję urządzeń komunikacyjnych i informatycznych oraz usługi towarzyszące w postaci oprogramowania, usług IT oraz usług telekomunikacyjnych (Cygler, 2003).

W literaturze przedmiotu wyraźnie wskazuje się na tzw. bezpośredni i pośredni wpływ sektora ICT na produktywność pracy w gospodarce (rozumianej jako stosunek produkcji globalnej lub wartości dodanej do liczby roboczogodzin). Koncepcja bezpośrednich efektów ICT, ściśle wywodząca się z neoklasycznej teorii wzrostu, wskazuje na ich dwa rodzaje. Po pierwsze, pozytywna zmiana technologiczna (postęp techniczny) w sektorach wytwarzających dobra i usługi informacyjno-komunikacyjne (ang. ICT producing sectors) powoduje wzrost łącznej produktywności czynników produkcji (ang. Total Factor Productivity TFP) na skutek pojawienia się tzw. finansowych efektów zewnętrznych. Efekt ten jest proporcjonalny do rozmiarów sektora ICT w danej gospodarce (O’Mahony i Timmer, 2008; Biagi, 2013). Po drugie, postęp techniczny w sektorze ICT stymuluje inwestycje w innych sektorach użytkujących technologie informacyjno-komunikacyjne (ang. ICT using sectors). Zwiększenie przeciętnej wydajności 
pracy w gospodarce wynika w tym przypadku ze wzrostu technicznego uzbrojenia pracy, będącego skutkiem akumulacji kapitału (ang. capital deepening), zwłaszcza tzw. kapitału ICT w tych sektorach (Arendt, 2016).

Koncepcja pośredniego wpływu sektora ICT na produktywność pracy, osadzona w nowej teorii wzrostu gospodarczego, wywodzi się z założenia, iż ICT jest technologią ogólnego zastosowania (ang. General Purpose Technology - GPT). Oznacza to, że w sektorach wykorzystujących ICT, z reguły po jakimś czasie potrzebnym na odpowiednie procesy dostosowawcze, pojawiają się innowacje produktowe, procesowe i organizacyjne, czyli tzw. efekty spillover (niefinansowe efekty zewnętrzne), które wpływają pozytywnie na TFP (Bresnahan i Trajtenberg, 1995). Poprawa innowacyjności sektorów inwestujących w ICT wpływa na długofalowy wzrost produktywności pracy, wzmacniając pierwotne korzyści wynikające z postępu technicznego generowanego przez sektor ICT (OECD, 2012).

Pierwsze dowody na pozytywny wpływ sektora ICT na produktywność pracy można odnaleźć w badaniach dla USA, uwzględniających drugą połowę lat 90. XX w. W okresie po 1995 r. obserwowano jednocześnie odwrócenie się wieloletniego trendu relatywnie niższego tempa wzrostu produktywności w USA względem ówczesnych 15 krajów członkowskich Unii Europejskiej (UE-15). W okresie 1996-2019 to USA wykazywały znacznie wyższą dynamikę produktywności pracy niż kraje „byłej piętnastki”, a powstała luka utrzymywała się nawet po 2007 r., kiedy z powodu światowego kryzysu (2008-2009) i jego następstw, kryzysu w strefie euro (2011-2012), jak i czynników strukturalnych obserwowano wyraźne spowolnienie tempa wzrostu produktywności w obu regionach (van Ark, 2016; Atkinson, 2018, OECD, 2019).

Celem artykułu jest weryfikacja hipotezy o istotnym związku rozwoju sektora ICT z poziomem luki produktywności między krajami Unii Europejskiej i USA w okresie 1996-2007 (wysokiego wzrostu produktywności pracy) oraz 2007-2017 (jej wyraźnego spadku w obu regionach). Analizę bezpośredniego i pośredniego wpływu sektora ICT na różnice w produktywności pracy przeprowadza się na poziomie makroekonomicznym oraz sektorowym, wykorzystując rachunek produktywności KLEMS.

\section{ICT a produktywność pracy - podejście metodologiczne}

Biorąc pod uwagę bezpośredni i pośredni wpływ sektora ICT na produktywność pracy w gospodarce, $\mathrm{w}$ badaniach stosuje się dwa różne podejścia metodolo- 
giczne. Pierwsze z nich bazuje na założeniach neoklasycznej teorii wzrostu gospodarczego i wykorzystuje metodologię rachunkowości wzrostu, tj. koncepcję dekompozycji wzrostu gospodarczego zapoczątkowaną przez Solowa (1957) i rozwiniętą metodologicznie przez Jorgensona (1963) i współpracowników (Jorgenson i Griliches, 1967; Jorgenson, Ho i Stiroh, 2005). Bezpośrednią zależność między rozwojem sektora ICT a wzrostem produktywności pracy w gospodarce można wyprowadzić bowiem z neoklasycznego modelu Solowa-Swana (Solow, 1957; Swan, 1956). W modelu tym produkcja (Y) w kraju $i$ w czasie $t$ jest funkcją nakładów pracy (L), kapitału (K) i postępu technologicznego (A).

(1) $Y_{i t}=f\left(A_{i t}, L_{i t}, K_{i t}\right.$

Przyjmując, że powyższa funkcja produkcji ma postać funkcji Cobba-Douglasa (uwzględniającą występowanie malejącej krańcowej produktywności czynników produkcji oraz stałych efektów skali), można ją zapisać w następującej postaci:

(2) $Y_{i t}=A_{i t}\left(L_{i t}^{\alpha} K_{i t}^{1-\alpha}\right)$

gdzie: a i (1- $\alpha)$ - elastyczność produkcji względem odpowiednio zasobów pracy i kapitału.

Postęp techniczny, utożsamiany w tym przypadku z TFP, ma charakter egzogeniczny i jest neutralny w sensie Hicksa.

Logarytmując stronami równanie (2) i różniczkując po czasie, otrzyma się funkcję (3) wskazującą na zmiany produkcji w gospodarce zależne od stopy wzrostu zasobów kapitału, zasobów pracy (godziny pracy) oraz postępu technicznego:

(3) $\Delta \ln Y_{i t}=\Delta \ln A_{i t}+\alpha \Delta \ln L_{i t}+(1-\alpha) \Delta \ln K_{i t}$

Przeprowadzając modyfikację tradycyjnej dekompozycji wzrostu ujętej w równaniu (3) zgodnie z metodologią rachunku produktywności gospodarki KLEMS, można uwzględnić, oprócz zasobów pracy rozumianych jako godziny $\operatorname{pracy}\left(L_{i t}\right)$, także ich czynnik jakościowy w postaci zasobów kapitału ludzkiego $\left(H_{i t}\right)$. Dodatkowo można także dokonać rozróżnienia między tzw. kapitałem ICT (ang. ICT capital), obejmującym dobra i usługi sektora ICT, oraz pozostałym kapitałem rzeczowym (ang. non-ICT capital). 
Wówczas równanie (3) można zapisać jako:

(4) $\Delta \ln Y_{i t}=\Delta \ln A_{i t}+\alpha \Delta \ln L_{i t}+\beta \Delta \ln H_{i t}+\gamma \Delta \ln K_{i t}^{I C T}+(1-\alpha-\beta-\gamma) \Delta \ln K_{i t}^{n o n-I C T}$

Odpowiednie matematyczne przekształcenia równania (4) pozwalają z kolei otrzymać następującą jego postać:

(5) $\Delta \ln y_{i t}=\Delta \ln A_{i t}+\beta \Delta \operatorname{lnh} h_{i t}+\gamma \Delta \ln k_{i t}^{I C T}+(1-\alpha-\beta-\gamma) \ln k_{i t}^{n o n-I C T}$

gdzie:

$y_{i t}=Y_{i t} / L_{i t}-$ produktywność pracy w gospodarce,

$A_{i t}-$ TFP (postęp techniczny),

$h_{i t}=H_{i t} / L_{i t}$ - tzw. kompozycja pracy (ang. labor composition), wyrażająca stosunek pracy wykwalifikowanej (tzw. usługi pracy) do ogólnych zasobów pracy (roboczogodzin),

$k_{i t}^{I C T}=K_{i t}^{I C T} / L_{i t}-$ kapitał ICT przypadający na roboczogodzinę, $k_{i t}^{\text {non-ICT }}=K_{i t}^{\text {non-ICT }} / L_{i t}-$ pozostałe zasoby kapitału na roboczogodzinę.

Równanie (5) wskazuje zatem, że przyrost produktywności pracy w gospodarce może być uzyskany poprzez podniesienie jakości zasobów pracy (kapitału ludzkiego), wzrost wykorzystania kapitału ICT i non-ICT oraz TFP.

W przypadku przyjęcia założeń, że rynki są doskonale konkurencyjne, a cena czynników produkcji jest równa ich produktywności krańcowej, oraz występowania stałych korzyści skali można przyjąć, że elastyczność produkcji względem nakładów poszczególnych czynników produkcji jest równoznaczna z udziałem ich wynagrodzenia w łącznym wynagrodzeniu czynników produkcji - (Kotlewski, Błażej, 2016; WIIW, 2019), a zatem równanie (5) można zapisać jako:

(6) $\Delta \ln y_{i t}=\Delta \ln A_{i t}+\vartheta_{L i t} \Delta \operatorname{lnh} h_{i t}+\vartheta_{I C T i t} \Delta \ln k_{i t}^{I C T}+\vartheta_{\text {nonICTit }} \Delta \ln k_{i t}^{\text {non-ICT }}$

Poszczególne wyrażenia po prawej stronie równania (6) można rozumieć jako kontrybucję odpowiednio TFP, kapitału ludzkiego, kapitału ICT i pozostałego kapitału we wzroście produktywności w gospodarce1.

${ }^{1}$ Kontrybucję (ang. contribution) czynników produkcji rozumie się jako ich wkład (udział) w dynamikę produktywności pracy w gospodarce. Termin ten stosuje się częściej w literaturze anglojęzycznej, natomiast w Polsce m.in. w opracowaniach Departamentu 
W kontekście rozwoju sektora ICT istotne znaczenie ma kontrybucja TFP i zasobów kapitału ICT w sektorach wdrażających technologie informatyczno-telekomunikacyjne. Z przedstawionego modelu bazującego na teorii neoklasycznej wynika bowiem, że:

a) postęp techniczny w sektorze ICT transferowany poprzez niższe ceny dóbr (finansowe efekty zewnętrzne) przekłada się na wyższą efektywność wszystkich czynników produkcji i ma pozytywny wpływ na TFP, przy czym siła owego wpływu zależy od rozmiarów sektora ICT;

b) postęp techniczny w sektorze ICT generuje popyt na technologie informatyczno-komunikacyjne (kapitał ICT) w pozostałych sektorach, a tego typu inwestycje, tożsame z powiększaniem zasobów kapitału, prowadzą do wzrostu produktywności pracy.

W przypadku pojawienia się wspomnianych już niefinansowych efektów zewnętrznych (efektów spillover) możliwy jest dodatkowy wzrost produktywności (wzrost TFP) w sektorach implementujących tego typu technologie (Biagi, 2013; Arendt, 2016). Te efekty pośrednie nie mogą być jednak do końca uchwycone w przypadku zastosowania opisanej powyżej metodologii. Do ich oszacowania można wykorzystać drugie podejście metodologiczne wywodzące się z nowej teorii wzrostu i jej założeń, wykorzystujące modelowanie ekonometryczne, tj. regresje wzrostu. W tym przypadku możliwa jest większa elastyczność w badaniu związku między wzrostem produktywności pracy w gospodarce a jej determinantami, które mogą obejmować dodatkowo efekty spillover ${ }^{2}$ (Biagi, 2013).

Alternatywnym podejściem w kierunku - przynajmniej częściowej oceny pośredniego wpływu rozwoju sektora ICT na wzrost produktywności pracy w gospodarce może być rachunek produktywności na poziomie sektorowym. Analiza kontrybucji sektora ICT we wzroście zagregowanego TFP może rzucić dodatkowe światło na źródła zmian produktywności

Studiów Makroekonomicznych i Finansów GUS zajmującego się sporządzaniem rachunku produktywności KLEMS dla Polski.

${ }^{2}$ To podejście metodologiczne bazuje na założeniach nowej torii wzrostu, co wymaga oszacowania poszczególnych parametrów równania

$$
\Delta \ln y_{i t}=\beta \Delta \ln h_{i t}+\gamma \Delta \ln k_{i t}^{I C T}+(1-\alpha-\beta-\gamma) \ln k_{i t}^{n o n-I C T}+\varepsilon_{i t}
$$

metodami ekonometrycznymi. Po oszacowaniu parametrów strukturalnych modelu możliwe jest wyliczenie wzrostu TFP za pomocą następującej formuły:

$$
\Delta T F P=\widehat{\varepsilon_{l t}}=\ln y_{i t}-\hat{\beta} \Delta \ln h_{i t}-\hat{\gamma} \Delta \ln k_{i t}^{I C T}+(1-\widehat{\alpha-\beta}-\gamma) \ln k_{i t}^{\text {non-ICT }} .
$$

$\mathrm{W}$ takiej sytuacji możliwe jest także wprowadzenie dodatkowych zmiennych aproksymujących efekty skali, czy efekty spillover. 
pracy zarówno w poszczególnych krajach, jak i wybranych przedziałach czasowych (Timmer i van Ark, 2005). Powyższe rozwiązanie stosuje się w niniejszym artykule.

\section{ICT a luka produktywności między UE i USA - zarys dotychczasowych badań empirycznych}

Podejście metodologiczne bazujące na neoklasycznej teorii wzrostu było i nadal jest stosowane w badaniu wpływu sektora ICT na zmiany produktywności pracy w Unii Europejskiej czy w USA. Większość badań koncentrujących się na wpływie rozwoju sektora ICT na produktywność pracy w Unii Europejskiej prowadzonych od początku XXI w. potwierdzała istnienie powyższej zależności, przy czym oceniano ją jako znacznie słabszą niż dla USA (Schreyer, 2000; Daveri 2000; van Ark, 2000; Strauss, Samkharadze i Besik, 2011). Van Welsum, Overmeer i van Ark (2013) udowodnili, że w okresie 1995-2007 na sektor ICT przypadło 1,3 punktu procentowego przeciętnej stopy wzrostu produktywności USA, podczas gdy w 15 krajach członkowskich Unii Europejskiej tylko 0,7 p.p. Istotne znacznie sektora ICT na wzrost produktywności udowadniano także na poziomie sektorowym (Corry i in., 2011).

Znacznie większa rozbieżność w wynikach badań miała miejsce w przypadku prób poszukiwania przyczyn luki produktywności między krajami UE i USA. Roeger (2001) jako przyczynę wskazywał wyższe tempo postępu technicznego w amerykańskim sektorze ICT (i wywołanego nim wzrostu TFP), udowadniając, że produktywność w USA rosła na skutek wzrostu rozmiarów sektora ICT, jak i tempa akumulacji kapitału ICT w innych sektorach, podczas gdy w krajach UE wyłącznie po wpływem tego drugiego czynnika. Podobne wnioski ze swoich badań wysunęli Strauss i Samkharadze (2011), twierdząc, że od 1995 r. w Unii Europejskiej (UE-15) w przeciwieństwie do USA obserwowano spadek TFP i niskie tempo akumulacji kapitału ICT. Timmer i van Ark (2005) badając powyższe bezpośrednie kanały wpływu ICT na produktywność, również udowodnili, że w okresie 1995-2001 w pełni determinowały one przewagę USA nad UE. Dystans ten w ponad 50\% wynikał z wyższego tempa inwestycji w kapitał ICT w USA niż UE, a w pozostałej części z szybszego rozwoju amerykańskiego sektora produkującego dobra ICT (np. półprzewodniki). Podobne konkluzje wynikają także z badania van Arka, O’Mahony’ego i Timmera (2008), którzy udowodnili, że niższe tempo wzrostu produktywności w UE w okresach 
1973-1995 i 1996-2006 wynikało z relatywnie niższej kontrybucji kapitału ICT i TFP $\mathrm{w}$ porównaniu $\mathrm{z}$ USA.

W niektórych badaniach kwestionowano jednak istotną rolę rozmiarów sektora ICT, wskazując, że nie jest warunkiem niezbędnym w stymulowaniu produktywności pracy i zmian luki między UE i USA (Pilat i Lee, 2001; Oulton, 2010). Przyczynę upatrywano jedynie w relatywnie niższym wzroście akumulacji kapitału ICT w krajach UE w porównaniu z USA (zob. Colecchia, Schreyer, 2001; Vijselaar, Albers, 2002). Atkinson (2018) np. udowodnił, że przyrost produktywności w USA w okresie 2013-2015 w 30\% był determinowany przez wzrost akumulacji dóbr i usług sektora ICT, podczas gdy w krajach UE w 7-23\%.

Wyniki dotychczasowych badań bazujących na metodologii rachunku produktywności wskazywały także na znaczenie pośredniego kanału oddziaływania ICT na lukę produktywności UE-USA. W badaniach na poziomie sektorowym potwierdzano, że kraje UE w porównaniu z USA cechowała niższa dynamika TFP w sektorach implementujących ICT, np. sektorze usług (Daveri, 2002, 2004; van Ark i in., 2003). Podejmowano także próby oszacowania wpływu tych sektorów na zmiany luki produktywności między UE i USA. Van Ark i inni (2003) oszacowali go na blisko 60\%, a Daveri (2004), wykorzystując nieco inną metodologię - na 38\%. Również van Ark, O’Mahony i Timmer (2008) nie wykluczali, że niższy przyrost TFP w UE niż w USA częściowo miał związek brakiem dodatkowych efektów wdrażania ICT (wzrostu TFP) w europejskim sektorze usług (handlowych, transportowych, finansowych i biznesowych).

Warto dodać, że większość przytoczonych badań obejmowało okres 1995-2007, a zatem czas dynamicznego wzrostu produktywności, zwłaszcza w USA. Okres po 2007 r. (istotnego spadku produktywności w obu regionach) był przedmiotem znacznie mniejszego zainteresowania ze strony ekonomistów. W dotychczasowych badaniach rzadko uwzględniano także tzw. nowe kraje członkowskie UE (UE-13). Niniejszy artykuł można zatem traktować jako próbę uzupełnienia powyższej luki w badaniach.

\section{Luka produktywności między UE i USA w okresie 1996-2019}

Analizując kształtowanie się luki produktywności pracy między UE (w tym jej poszczególnymi podgrupami) i USA w latach 1996-2019, można wyróżnić kilka podokresów. W okresie do 2000 r. tzw. stare kraje członkowskie UE (UE-15) utrzymywały jeszcze (ogólnie rzecz biorąc) wyższy poziom PKB przypadający 
na roboczogodzinę (50-54 USD) niż USA, przy czym przewaga ta stopniowo się zmniejszała. W tym czasie dystans do USA pod względem poziomu produktywności, zarówno ówczesnych krajów kandydujących do UE (UE-13), jak i całej grupy UE-28, powiększał się (do odpowiednio 30 USD dla UE-13 oraz 13 USD dla UE-28 w 2000 r.). USA wykazywały bowiem wyższy średnioroczny wzrost produktywności $(2,5 \%)$ niż kraje byłej piętnastki $(1,8 \%)$ i zbliżony do tego osiąganego średnio w 28 krajach dzisiejszej UE (2,7\%).

Po 2001 r. także w odniesieniu do krajów grupy UE-15 obserwowano pogłębiającą się lukę produktywności pracy względem USA (wyjątek stanowiły takie kraje jak Belgia, Dania, Niemcy, Francja, Luksemburg i Holandia). Powyższy trend utrzymywał się w krajach UE-15, jak i całej grupie UE-28 w zasadzie do 2019 r., kiedy produktywność pracy osiągnęła poziom odpowiednio 64 USD i 53 USD na 1 roboczogodzinę, a zatem o 10 USD i 21 USD niższy niż w USA. Odwrócenie powyższej tendencji miało miejsce jedynie w grupie nowych krajów członkowskich UE, które od 2010 r. zaczęly nieznacznie zmniejszać swój dystans do USA (zob. rysunek 1).

Rysunek 1. Luka produktywności UE (UE-15/UE-13) względem USA w okresie 1996-2019 (różnica w PKB na roboczogodzinę, USD, ceny stałe 2018)

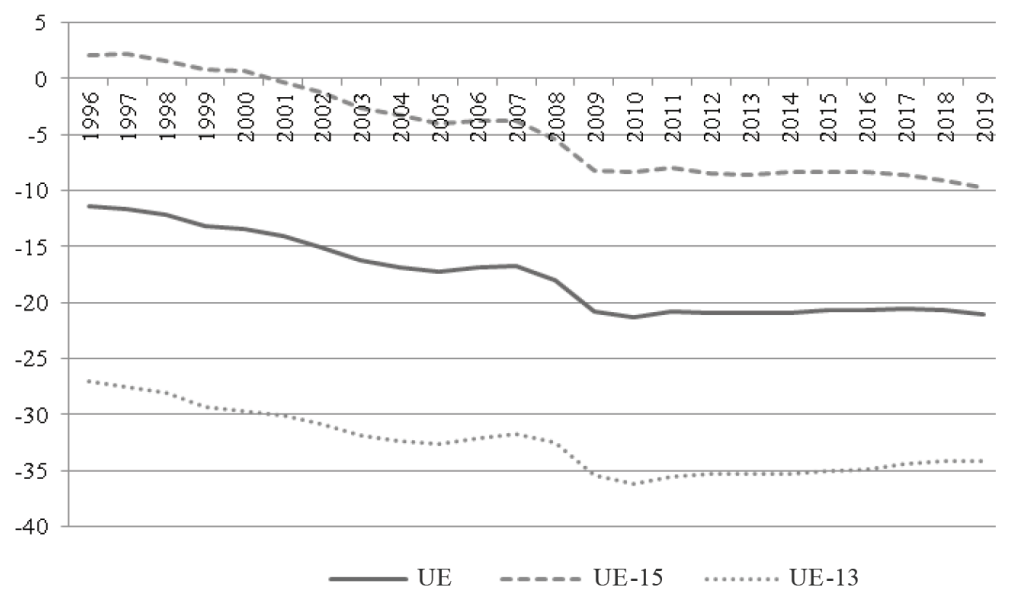

Źródło: obliczenia własne na podstawie The Conference Board Total Economy Database.

W okresie 1996-2019 dynamika produktywności pracy w krajach członkowskich UE i USA, a tym samym omawianej luki, wykazywała dość znaczne zróżnicowanie. Na okres 1996-2007 przypadał wysoki wzrost produktywności pracy w obu regionach. W USA był on jednak średnio o 0,75 p.p. wyższy niż w krajach byłej piętnastki. Kraje grupy UE-13 rozwijały się szybciej pod tym 
kątem niż USA (średnioroczna stopa wzrostu wyższa o 1,75 p.p. niż w USA). Warto dodać, że były to kraje o znacznie niższym wyjściowym poziomie produktywności, wchodzące na ścieżkę szybkiego wzrostu gospodarczego wspartego odpowiednimi reformami związanymi z transformacją gospodarek i przyszłym członkowstwem w UE (zob. rysunek 2).

Rysunek 2. Średnioroczna dynamika produktywności pracy w UE (UE-15/UE-13) i USA (\%) w okresie 1996-2019

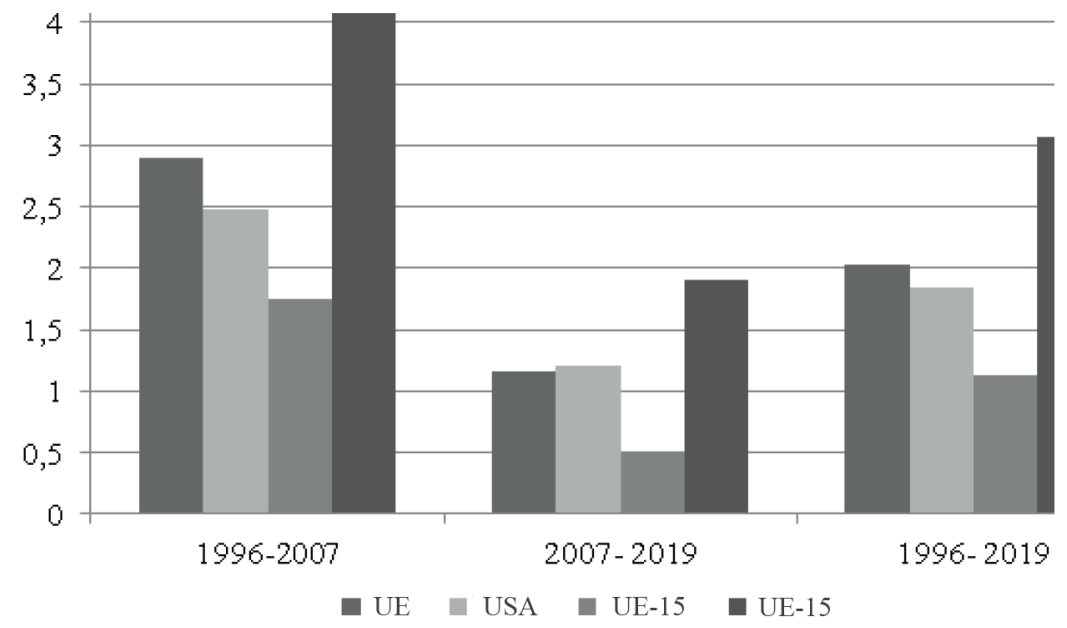

Źródło: obliczenia własne na podstawie The Conference Board Total Economy Database.

W konsekwencji na okres 1996-2007 przypada znacznie szybsze tempo powiększania się luki produktywności UE (zwłaszcza krajów byłej piętnastki) względem USA. W przypadku UE rozszerzonej do 28 krajów luka powiększała się znacznie wolnej ze względu na szybkie nadrabianie dystansu przez kraje grupy UE-13.

W okresie 2007-2019 dynamika produktywności pracy wyraźnie osłabła. Jej średnioroczne tempo wzrostu w USA spadło o połowę (do 1,21\%), w UE o $60 \%$ (do 1,16\%), w tym w grupie UE-15 o 70\% (do 0,52\%). Najniższy spadek dynamiki w analizowanym okresie, podobny do tego dla USA, wykazywały kraje grupy UE-13, zwiększając produktywność średnio o 1,9\% rocznie. W tym czasie analizowana luka na linii UE-USA ustabilizowała się, a w przypadku nowych krajów członkowskich nieznacznie się zmniejszyła. 


\section{Znaczenie sektora ICT w kształtowaniu luki produktywności między UE i USA - badanie na podstawie rachunku produktywności}

W badaniu wpływu sektora ICT na tempo produktywności pracy w krajach UE i USA wykorzystano rachunek produktywności KLEMS, którego podstawy metodologiczne omówiono powyżej. Analizie poddano zatem dekompozycję przyrostu wartości dodanej brutto (na 1 roboczogodzinę) na kontrybucję poszczególnych czynników produkcji, opisaną równaniem (6). Ze względu na brak danych statystycznych w bazie danych KLEMS dla niektórych krajów UE analizę w okresie 1996-2007 ograniczono do 11 „starych” i 2 „nowych” krajów członkowskich. W badaniu dla lat 2007-2017 powyższe grupy poszerzono do odpowiednio 15 i 9 krajów.

W okresie 1996-2007 średnioroczny wzrost produktywności pracy w USA wynosił 2,3\%, podczas gdy w „starych” krajach UE 1,6\%. Relatywnie wyższą dynamikę produktywności miały Czechy i Słowacja, bo ok. 4-5\% (zob. tabela 1). 
Artykuł ekonomiczny | 37

\begin{tabular}{|c|c|c|c|c|c|c|c|c|c|c|c|c|c|}
\hline \multirow{12}{*}{ 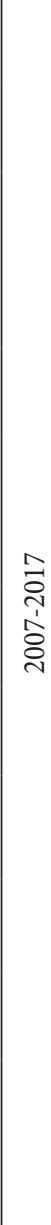 } & 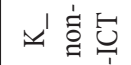 & \multirow{6}{*}{ 岇 } & I & in & I & $\stackrel{g}{g}$ & $\stackrel{\circ}{\approx}$ & ô & $\stackrel{\vec{v}}{\vec{v}}$ & $\begin{array}{l}0 \\
\hat{0} \\
0\end{array}$ & $\begin{array}{c}\frac{H}{0} \\
\text { s. }\end{array}$ & \multirow{6}{*}{ 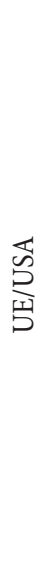 } & त్ \\
\hline & $\varkappa^{\prime}$ & & 8 & $\stackrel{0}{\infty}$ & $\Rightarrow$ & $\frac{ \pm}{0}$ & $\exists$ & 8 & ô & $\begin{array}{l}n \\
0 \\
i\end{array}$ & 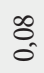 & & c \\
\hline & I & & $\stackrel{\infty}{\infty}$ & तु & $\begin{array}{l}+ \\
0 \\
0\end{array}$ & $\overrightarrow{\tilde{N}_{1}}$ & $\tilde{6}$ & $\begin{array}{l}0 \\
2 \\
0\end{array}$ & $\stackrel{8}{0}$ & $\begin{array}{l}\infty \\
0 \\
0 \\
0\end{array}$ & $\tilde{\delta}$ & & \\
\hline & 疍 & & $\begin{array}{l}\infty \\
\stackrel{0}{0}\end{array}$ & $\begin{array}{l}0 \\
\text { In } \\
0\end{array}$ & ते & \begin{tabular}{l}
0 \\
\multirow{1}{*}{} \\
0
\end{tabular} & గి & $\underset{\exists}{ت}$ & $\stackrel{\Xi}{0}$ & $\begin{array}{l}\circ \\
0\end{array}$ & $\stackrel{\overbrace =}{-}$ & & 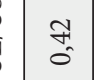 \\
\hline & 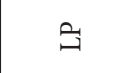 & & $\begin{array}{l}\stackrel{0}{i} \\
i\end{array}$ & $\stackrel{m}{\rightarrow}$ & $\underset{\sim}{\stackrel{v}{c}}$ & $\begin{array}{l}m \\
0 \\
0\end{array}$ & $\stackrel{R}{\stackrel{i}{i}}$ & $\stackrel{\infty}{m}$ & $\hat{~}$ & $\cong$ & $\underset{\substack{0 \\
i}}{i}$ & & \\
\hline & 矛莺 & & 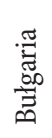 & $\begin{array}{l}\hat{\bar{E}} \\
\hat{\mathcal{U}}\end{array}$ & 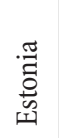 & 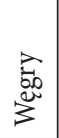 & 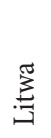 & 莺 & 覓 & 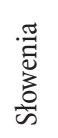 & 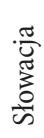 & & \\
\hline & 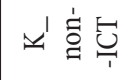 & \multirow{6}{*}{ 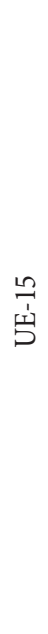 } & 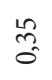 & $\stackrel{m}{0}$ & ${ }_{0}^{\circ}$ & $\approx$ & 要 & $\begin{array}{l}0 \\
0 \\
0\end{array}$ & $\hat{\tilde{c}}$ & $\tilde{O}_{0}$ & $\stackrel{\pi}{\sim}$ & ڤ్ & \\
\hline & $x^{\prime}$ & & $\stackrel{n}{\circ}$ & $\stackrel{\widetilde{c}}{0}$ & 8 & $\frac{0}{0}$ & & $\stackrel{\infty}{0}$ & $\stackrel{8}{0}$ & $\hat{0}$ & oे & ठै. & \\
\hline & 壮 & & $\frac{0}{0}$ & $\overrightarrow{\tilde{\sigma}}$ & oे & 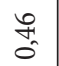 & $\hat{\sigma}$ & in & $\overrightarrow{\tilde{\sigma}}$ & $\begin{array}{l}\mathbb{H} \\
0\end{array}$ & $\begin{array}{l}\text { t. } \\
\text { On }\end{array}$ & ণ্ & \\
\hline & 偪 & & o. & $\frac{\pi}{0}$ & 苛 & $\tilde{o}$ & & ֻُ & $\stackrel{m}{0}$ & 菅 & 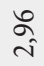 & กี & \\
\hline & G & & $\begin{array}{l}\vec{\infty} \\
0 \\
0\end{array}$ & $\begin{array}{l}\vec{n} \\
0 \\
0\end{array}$ & $\begin{array}{l}0 \\
0 \\
0\end{array}$ & $\begin{array}{l}1 \\
0 \\
0\end{array}$ & & $\stackrel{\infty}{\sim}$ & F & $\begin{array}{l}8 \\
10 \\
0 \\
0\end{array}$ & $\underset{\infty}{\infty}$ & $\begin{array}{l}0 \\
0 \\
0\end{array}$ & \\
\hline & 可 & & 莺 & 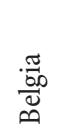 & 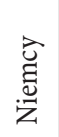 & $\begin{array}{l}\text { 范 } \\
\text { ص }\end{array}$ & $\frac{\sigma}{\tilde{u}}$ & 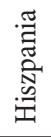 & $\begin{array}{l}\text { 妥 } \\
\text { 胥 } \\
\text { 婊 }\end{array}$ & $\begin{array}{l}\text { 㺃 } \\
\text { 营 }\end{array}$ & $\begin{array}{l}\text { 孚 } \\
\stackrel{\Xi}{\Xi} \\
\stackrel{\Xi}{\exists}\end{array}$ & 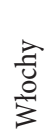 & \\
\hline \multirow{5}{*}{ 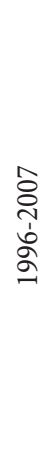 } & 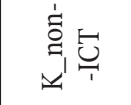 & 年 & $\begin{array}{l}0 \\
3 \\
0 \\
0\end{array}$ & F & 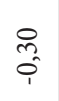 & $\overrightarrow{0}$ & $\hat{0}$ & 8 & $\tilde{\approx}$ & $\stackrel{0}{0}$ & $\begin{array}{l}\infty \\
0 \\
0\end{array}$ & 年 & \\
\hline & $\varkappa^{\prime}$ & $\begin{array}{l}0 \\
0 \\
0\end{array}$ & o & $\stackrel{2}{0}$ & $\begin{array}{l}20 \\
0\end{array}$ & $\stackrel{\sim}{\sigma}$ & $\overrightarrow{0}$ & $\stackrel{0}{0}$ & $\stackrel{8}{0}$ & $\overrightarrow{\tilde{\sigma}}$ & तु & $\frac{a}{0}$ & \\
\hline & I & s. & $\begin{array}{l}\text { in } \\
0\end{array}$ & $\overrightarrow{0}$ & $\tilde{\sigma}_{0}^{\infty}$ & స్ & $\stackrel{\pi}{3}$ & $\stackrel{\text { In }}{0}$ & 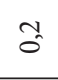 & $\vec{m}$ & $\underset{\sim}{\rightarrow}$ & $\begin{array}{l}0 \\
0 \\
0 \\
0\end{array}$ & \\
\hline & 屆 & $\stackrel{\infty}{=}$ & $\begin{array}{l}R \\
0 \\
0\end{array}$ & $\stackrel{9}{+}$ & $\begin{array}{l}\infty \\
\infty \\
0 \\
0\end{array}$ & $\begin{array}{c}\infty \\
0 \\
0 \\
i\end{array}$ & & $\stackrel{\sim}{=}$ & $\frac{\pi}{i}$ & $\stackrel{n}{\alpha}$ & F & $\approx$ & \\
\hline & : & $\stackrel{\Re}{=}$ & $\vec{m}$ & $\stackrel{\infty}{\infty}$ & $\hat{\circ}$ & $\tilde{\Xi}$ & ్ָ & $\vec{i}$ & $\begin{array}{l}\sharp \\
0 \\
0\end{array}$ & $\stackrel{\beta}{-}$ & $\stackrel{8}{:}$ & $\stackrel{\sim}{\vec{i}}$ & \\
\hline & 串芯 & 莺 & $\frac{. \breve{5}}{\varpi}$ & $\begin{array}{l}\widehat{\breve{̆}} \\
\overline{\underline{u}} \\
\bar{z}\end{array}$ & 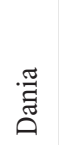 & 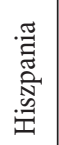 & ] & $\begin{array}{l}\text { 㺃 } \\
\text { 莹 }\end{array}$ & 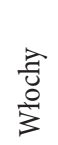 & 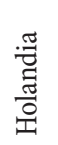 & $\begin{array}{l}\text { 莺 } \\
\text { 芯 }\end{array}$ & 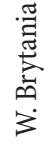 & \\
\hline
\end{tabular}


38 | Przegląd Prawno-Ekonomiczny

\begin{tabular}{|c|c|c|c|c|c|c|c|c|c|}
\hline \multirow{12}{*}{ 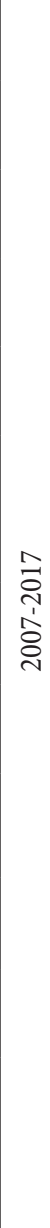 } & 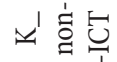 & $\stackrel{+1}{n}$ & 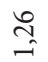 & 능 & & $\hat{\alpha}$ & & & \\
\hline & $\varkappa^{\prime}$ & $\begin{array}{l}\infty \\
0 \\
0\end{array}$ & $\tilde{\sigma}_{0}^{0}$ & $\begin{array}{l}\text { tr } \\
\text { i }\end{array}$ & & $\begin{array}{l}\text { oे } \\
0 \\
1\end{array}$ & & & \\
\hline & 工 & $\begin{array}{l}\infty \\
n_{0}^{2}\end{array}$ & O⿱ & $\overrightarrow{\tilde{\sigma}}$ & & $\tilde{\tilde{o}}$ & & & \\
\hline & 突 & $\stackrel{n}{0}$ & 웅 & in & & ô. & & & \\
\hline & 의 & $\begin{array}{l}0 \\
\stackrel{0}{0}\end{array}$ & $\stackrel{\circ}{\stackrel{0}{v}}$ & $\stackrel{H}{i}$ & & $\stackrel{ }{=}$ & & & \\
\hline & 矛急 & $\begin{array}{l}\frac{10}{5} \\
\text { 兵 }\end{array}$ & 辛 & $\stackrel{\widetilde{F}}{3}$ & 皇 & 孚 & 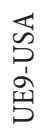 & & \\
\hline & 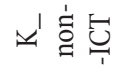 & $\frac{10}{2}$ & $\frac{\pi}{0}$ & $\stackrel{\infty}{1}$ & & $\frac{\pi}{0}$ & & & \\
\hline & $x^{\prime}$ & $\frac{m}{0}$ & $\stackrel{0}{0}$ & స్ & & है & & & \\
\hline & 工 & $\stackrel{m}{a}$ & $\underset{-}{-}$ & f & & $\begin{array}{l}0 \\
0 \\
0\end{array}$ & & & \\
\hline & 窝 & $\overrightarrow{\text { ç }}$ & Fi & in & & 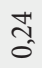 & & & \\
\hline & 言 & E. & $\stackrel{\infty}{0}$ & กิ & & $\stackrel{m}{m}$ & & & \\
\hline & 䨔 & 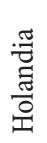 & 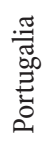 & 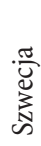 & & 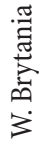 & & & \\
\hline \multirow{5}{*}{ 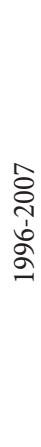 } & 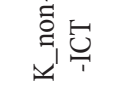 & to & in & స్ & \begin{tabular}{l}
$\infty$ \\
\hdashline \\
0
\end{tabular} & & $\begin{array}{c}m \\
\hat{0} \\
\text { ? }\end{array}$ & & $\frac{2}{0}$ \\
\hline & $\varkappa^{\prime}$ & $\begin{array}{l}0 \\
0 \\
0\end{array}$ & @ి & $\stackrel{m}{0}$ & $\stackrel{2}{a}$ & & $\stackrel{7}{0}$ & & $\frac{\infty}{0}$ \\
\hline & 工 & $\vec{m}$ & $\begin{array}{l}0 \\
0 \\
0\end{array}$ & के & के & & $\stackrel{\infty}{0}$ & & $\stackrel{\infty}{0}$ \\
\hline & 尼 & $\stackrel{\text { Lf }}{+}$ & $\stackrel{\overbrace{}}{-}$ & $\begin{array}{l}\infty \\
\infty \\
0\end{array}$ & $\frac{\sim}{m}$ & & $\begin{array}{l}\infty \\
\mathfrak{m}_{1}^{n} \\
\hat{i}\end{array}$ & & $\stackrel{-}{-\infty}$ \\
\hline & 겁 & $\stackrel{+}{\leftarrow}$ & $\stackrel{\infty}{\sim}$ & $\stackrel{\infty}{\infty}$ & $\stackrel{2}{2}$ & & ? & & $\stackrel{\infty}{\stackrel{i}{i}}$ \\
\hline & 㞼 & $\begin{array}{l}\frac{\sigma}{\widetilde{J}} \\
\frac{3}{3} \\
\frac{0}{\omega}\end{array}$ & 崩 & 孚 & 先 & $\stackrel{\widetilde{g}}{3}$ & 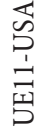 & $\stackrel{\widetilde{3}}{\Xi}$ & 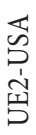 \\
\hline
\end{tabular}

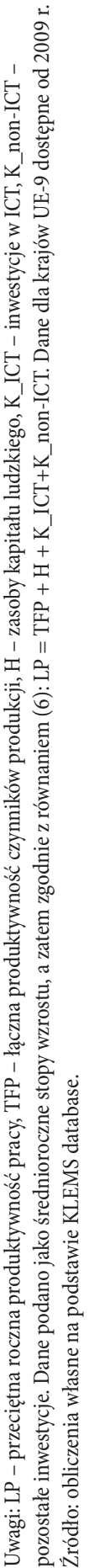


W przypadku USA wzrost produktywności pracy wynikał głównie ze wzrostu TFP (kontrybucja wynosiła 1,2 p.p.). Podobną lub wyższą kontrybucję TFP obserwowano jedynie w kilku krajach europejskich, tj. Niemczech, Finlandii, Francji, Wielkiej Brytanii oraz Czechach i Słowacji. Kraje te jako jedyne odnotowywały także zbliżony lub wyższy niż w USA wzrost produktywności pracy. Przeciętny wkład TFP we wzrost produktywności w grupie UE-11 był niższy i wynosił 0,9 p.p. W analizowanym okresie USA wykazywały także wyższą średnioroczną kontrybucję inwestycji w ICT niż kraje unijne (0,3 w porównaniu z ok. 0,13 p.p. w UE). Podobna sytuacja miała miejsce w przypadku pozostałych inwestycji (kapitał non-ICT), zwłaszcza porównując USA z grupą UE-11.

W krajach UE obserwowano jednak znacznie większy niż w USA wkład zasobów kapitału ludzkiego w kształtowaniu dynamiki produktywności (0,34 p.p. w porównaniu z 0,16 p.p. w USA). Na 0,7-punktową lukę produktywności między UE-11 i USA istotny wpływ miała przewaga USA wynikająca z rozwoju sektora ICT (łącznie 0,55 p.p. związane ze wzrostem TFP i inwestycji w ICT) oraz inwestycji w aktywa niezwiązane z ICT, niwelowana w pewnym stopniu za sprawą relatywnie wysokiej kontrybucji kapitału ludzkiego w krajach UE. Analizując dynamikę produktywności w Czechach i na Słowacji i ich przewagę o 2 p.p. nad USA, można stwierdzić, że wynikała ona w zasadzie ze wzrostu TFP oraz w niewielkim stopniu z akumulacji kapitału non-ICT (kontrybucja odpowiednio 1,9 i 0,19 p.p.).

W okresie 2007-2017 dynamika produktywności w UE, podobnie jak w USA, wyraźnie osłabła [wynosiła średnio 1\% w USA, 0,8\% w grupie UE-15 i 2,1\% w nowych krajach UE (UE-9)]. Wielu krajach członkowskich obserwowano jednocześnie spadek TFP, tj. jej ujemną kontrybucję do produktywności (Grecja, Hiszpania, Finlandia, Francja, Luksemburg, Portugalia, Estonia, Włochy, Węgry i Litwa). Wyjątkiem była Irlandia, a w grupie UE-9 Łotwa, Słowacja i Bułgaria, w przypadku których kontrybucja TFP utrzymała się na relatywnie wysokim dodatnim poziomie, a produktywność pracy rosła szybciej niż przeciętnie w UE i w USA.

Ogólnie rzecz biorąc, w krajach UE największy wkład w kształtowaniu dynamiki produktywności w tym okresie miały zasoby kapitału ludzkiego (kontrybucja przeciętnie na poziomie ok. 0,4 p.p.) oraz inwestycje w aktywa niezwiązane z sektorem ICT (0,3 p.p. w UE-15 oraz ok. 1,3 p.p. w grupie UE-9). W przeciwieństwie do UE wzrost produktywności pracy w USA kształtowany był przez czynniki związane z rozwojem sektora ICT, tj. wzrost TFP oraz inwestycje w dobra i usługi z sektora ICT (kontrybucja wynosząca odpowiednio 0,42 i 0,12 p.p., a zatem łącznie 0,54 p.p. na 1\% wzrost produktywności). Analizując 
lukę produktywności między UE-15 i USA w okresie 2007-2017, można stwierdzić, że wynikała ona właśnie z przewagi USA w zakresie dynamiki tych dwóch ostatnich czynników. W USA obserwowano bowiem wyższą niż w UE kontrybucję TFP i kapitału ICT (łącznie o 0,49 p.p.). Niższa była z kolei kontrybucja zasobów kapitału ludzkiego i pozostałych inwestycji (o 0,25 p.p.), co sprawiło, że różnica stopy wzrostu produktywności między USA i UE wynosiła ostatecznie 0,24 p.p. Z kolei przewaga nowych krajów członkowskich UE o 1,1 p.p. nad USA pod względem tempa wzrostu produktywności była niemalże wyłącznie efektem relatywnie wyższej stopy wzrostu zasobów kapitału ludzkiego (o 0,23 p.p.) i inwestycji w aktywa spoza sektora ICT (o 0,97 p.p.).

Przedstawione wyniki, mimo że dostarczają dowodów na związek między rozwojem sektora ICT i luką produktywności UE-USA w obu analizowanych okresach, zwłaszcza zmian TFP, nie precyzują, w jakim stopniu zmiana TFP wynikała z postępu technicznego w sektorze ICT, a w jakim z pojawienia się efektów spillover w innych sektorach gospodarki. Niemożliwe jest zatem wskazanie na rozmiary bezpośrednich i pośrednich efektów ICT. Wobec powyższego przeprowadzono dodatkowe badanie na poziomie sektorowym. W związku z tym, że zagregowaną zmienną TFP z równania (6) można przedstawić jako średnią ważoną zmian TFP w poszczególnych sektorach gospodarki (wagami są udziały poszczególnych sektorów w zagregowanej wartości dodanej brutto), oszacowano kontrybucję TFP z sektora ICT (tj. trzech branż, które wg klasyfikacji EU KLEMS obejmują dobra i usługi ICT) w ogólnym wzroście produktywności w gospodarkach poszczególnych krajów (zob. tabela 2). Analizując otrzymane wyniki, można jednocześnie zauważyć, jaka część wzrostu zagregowanego TFP w omawianych krajach wynikała ze wzrostu TFP w sektorze ICT.

Tabela 2. Kontrybucja TFP z sektora ICT we wzroście produktywności pracy w UE i USA w okresie 1996-2007 i 2007-2017

\begin{tabular}{|l|c|c|c|c|c|c|c|c|c|c|}
\cline { 2 - 11 } \multicolumn{1}{c|}{} & \multicolumn{5}{|c|}{$1996-2007$} & \multicolumn{5}{c|}{ 2007-2017 } \\
\cline { 2 - 12 } & $\begin{array}{c}\text { TFP } \\
\text { zagreg. }\end{array}$ & C26 & C27 & J & $\begin{array}{c}\text { TFP } \\
\text { z ICT }\end{array}$ & $\begin{array}{c}\text { TFP } \\
\text { zagreg. }\end{array}$ & C26 & C27 & J & $\begin{array}{c}\text { TFP } \\
\text { z ICT }\end{array}$ \\
\hline Austria & 1,08 & $-0,01$ & 0,05 & 0,06 & 0,11 & 0,30 & 0,01 & 0,05 & 0,01 & 0,06 \\
\hline Belgia & 0,70 & 0,05 & 0,02 & 0,09 & 0,16 & 0,14 & 0,01 & $-0,01$ & 0,08 & 0,07 \\
\hline Niemcy & 1,40 & 0,15 & 0,03 & 0,23 & 0,40 & 0,64 & 0,09 & $-0,01$ & 0,14 & 0,23 \\
\hline Dania & 0,88 & 0,05 & $-0,01$ & 0,22 & 0,25 & 0,20 & 0,01 & 0,01 & 0,22 & 0,24 \\
\hline Finlandia & 2,16 & 0,62 & 0,04 & 0,24 & 0,90 & $-0,13$ & $-0,02$ & 0,01 & 0,18 & 0,17 \\
\hline
\end{tabular}


Artykuł ekonomiczny | 41

\begin{tabular}{|l|c|c|c|c|c|c|c|c|c|c|}
\hline & \multicolumn{7}{|c|}{$1996-2007$} & \multicolumn{5}{c|}{$2007-2017$} & TFP \\
\cline { 2 - 12 } & $\begin{array}{l}\text { TFP } \\
\text { zagreg. }\end{array}$ & C26 & C27 & J & $\begin{array}{c}\text { TFP } \\
\text { z ICT }\end{array}$ & $\begin{array}{c}\text { TFP } \\
\text { zagreg. }\end{array}$ & C26 & C27 & J & z ICT \\
\hline Francja & 1,23 & 0,07 & 0,01 & 0,14 & 0,23 & $-0,04$ & 0,04 & $-0,01$ & 0,03 & 0,06 \\
\hline Włochy & $-0,14$ & 0,00 & 0,00 & 0,11 & 0,10 & $-0,32$ & $-0,01$ & 0,00 & 0,01 & 0,00 \\
\hline Holandia & 0,95 & 0,11 & $-0,01$ & 0,17 & 0,27 & 0,21 & 0,01 & 0,01 & 0,04 & 0,06 \\
\hline Szwecja & 0,41 & 0,41 & 0,02 & 0,13 & 0,55 & $-0,45$ & 0,13 & 0,00 & 0,09 & 0,21 \\
\hline W. Brytania & 1,12 & 0,02 & 0,01 & 0,24 & 0,27 & 0,24 & 0,01 & 0,00 & 0,10 & 0,11 \\
\hline Czechy & 1,87 & 0,09 & 0,11 & 0,02 & 0,23 & 0,46 & 0,03 & 0,07 & 0,13 & 0,22 \\
\hline Słowacja & 4,45 & 0,12 & 0,06 & 0,06 & 0,24 & 1,63 & 0,11 & 0,14 & 0,07 & 0,32 \\
\hline USA & 1,23 & 0,34 & 0,01 & 0,31 & 0,66 & 0,42 & 0,11 & 0,00 & 0,32 & 0,42 \\
\hline UE-10 & 0,97 & 0,15 & 0,02 & 0,16 & 0,32 & 0,08 & 0,03 & 0,00 & 0,09 & 0,12 \\
\hline UE-2 & 3,12 & 0,11 & 0,08 & 0,04 & 0,23 & 1,04 & 0,07 & 0,10 & 0,10 & 0,27 \\
\hline
\end{tabular}

Uwagi: C26 - sprzęt komputerowy, elektroniczny i optyczny; C27 - sprzęt elektryczny; J - usługi informatyczno-komunikacyjne. Badaniem objęto tylko te kraje UE, dla których dostępne były dane na poziomie sektorowym. Dane podano jako średnioroczne stopy wzrostu.

Źródło: obliczenia własne na podstawie KLEMS database.

W obydwu analizowanych okresach kontrybucja TFP z sektorów ICT (w tym zwłaszcza z dwóch branż: produkcji sprzętu komputerowego i usług informatyczno-komunikacyjnych) w zagregowanym wzroście TFP była relatywnie wyższa w USA niż krajach UE (odpowiednio 0,66 i 0,42. p.p. wobec 0,32 i 0,12 p.p. w grupie UE-10 oraz 0,23 i 0,27 p.p. w UE-2). Wśród analizowanych krajów UE zbliżony do USA wzrost TFP w sektorze ICT odnotowywano jedynie w Finlandii, Niemczech, Danii i Szwecji. Warto zauważyć, że zwłaszcza w okresie 2007-2017 w wielu krajach unijnych obserwowano wzrost TFP w sektorze ICT przy jednoczesnym spadku (lub relatywnie niższym wzroście) wskaźnika zagregowanego, co wskazuje na ujemną kontrybucję TFP z pozostałych sektorów gospodarki.

Podsumowaniem przeprowadzonej analizy jest tabela 3, w której przedstawiono uszczegółowioną dekompozycję produktywności pracy, wskazując na bezpośredni i pośredni kanał oddziaływania sektora ICT. 


\begin{tabular}{|c|c|c|c|c|c|c|c|c|c|c|c|c|c|c|}
\hline \multirow{6}{*}{ 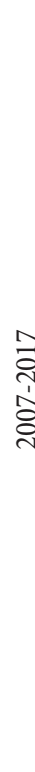 } & \multirow{2}{*}{\multicolumn{2}{|c|}{ 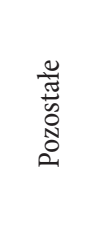 }} & 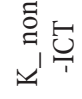 & 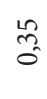 & $\stackrel{m}{0}$ & oे & $\begin{array}{l}\approx \\
0\end{array}$ & $\begin{array}{l}\hat{\sigma} \\
\text { ô }\end{array}$ & $\begin{array}{l}\text { ô } \\
0 \\
0\end{array}$ & $\begin{array}{l}\text { I } \\
\text { ô }\end{array}$ & $\frac{10}{0}$ & 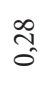 & $\begin{array}{l} \pm \\
0 \\
0\end{array}$ & $\begin{array}{l}\infty \\
\stackrel{2}{2} \\
0\end{array}$ \\
\hline & & & U & $\begin{array}{l}\text { 응 } \\
\text { a }\end{array}$ & $\begin{array}{l}\vec{\sim} \\
\tilde{\sigma}\end{array}$ & $\begin{array}{l}8 \\
0\end{array}$ & $\begin{array}{l}0 \\
\text { t. } \\
0\end{array}$ & $\begin{array}{l}\overrightarrow{\widetilde{\sigma}} \\
\text { }\end{array}$ & $\begin{array}{l}\mathbb{Z} \\
0\end{array}$ & గ్ర & $\stackrel{m}{a}$ & f & $\begin{array}{l}8 \\
0 \\
0\end{array}$ & $\underset{\tilde{O}}{\stackrel{\Delta}{0}}$ \\
\hline & & 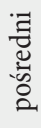 & 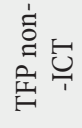 & $\begin{array}{l}\text { J } \\
\text { o }\end{array}$ & $\begin{array}{l}\hat{\sigma} \\
0\end{array}$ & $\begin{array}{l}F \\
\text { z }\end{array}$ & $\begin{array}{l}\text { t' } \\
\text { i }\end{array}$ & $\begin{array}{l}\text { m. } \\
\text { î }\end{array}$ & $\frac{0}{0}$ & $\begin{array}{l}\text { กै } \\
\hat{0}\end{array}$ & $\begin{array}{l}\stackrel{2}{2} \\
0\end{array}$ & $\begin{array}{l}\hat{0} \\
\hat{0}\end{array}$ & $\begin{array}{l}\dddot{m} \\
0\end{array}$ & $\begin{array}{l}\text { त } \\
\text { o }\end{array}$ \\
\hline & $\begin{array}{l}0 \\
0 \\
3 \\
\frac{3}{3} \\
3\end{array}$ & $\bar{Z}$ & 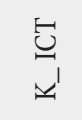 & $\stackrel{n}{0} 0$ & $\begin{array}{l}\text { ô } \\
\text { o }\end{array}$ & 8 & $\begin{array}{l}\stackrel{0}{0} \\
0\end{array}$ & $\begin{array}{l}8 \\
0 \\
0\end{array}$ & $\begin{array}{l}\hat{\sigma} \\
0\end{array}$ & $\begin{array}{l}\text { ô } \\
\text { Oे }\end{array}$ & $\frac{m}{0}$ & ָָ & $\sigma_{0}^{0}$ & $\stackrel{\infty}{0}$ \\
\hline & & ป & 突 & $\stackrel{8}{0}$ & $\hat{\sigma}$ & $\begin{array}{l}\tilde{y} \\
\tilde{0}\end{array}$ & ָू & $\frac{1}{0}$ & $\stackrel{8}{8}$ & \& & $\begin{array}{l}8 \\
0\end{array}$ & $\overrightarrow{\widetilde{\sigma}}$ & $\vec{z}$ & กี \\
\hline & \multicolumn{3}{|c|}{ G } & $\begin{array}{l}\vec{\infty} \\
0\end{array}$ & $\begin{array}{l}\vec{n} \\
0\end{array}$ & $\begin{array}{l}\widetilde{1} \\
0 \\
0\end{array}$ & $\begin{array}{l}\hat{\infty} \\
0 \\
0\end{array}$ & $\begin{array}{l}F \\
\text { O }\end{array}$ & $\begin{array}{l}0 \\
10 \\
0\end{array}$ & $\begin{array}{l}0 \\
\stackrel{0}{0}\end{array}$ & $\begin{array}{l}\overrightarrow{0} \\
0\end{array}$ & ก̂. & $\tilde{n}$ & $\stackrel{n}{m}$ \\
\hline \multirow{6}{*}{ 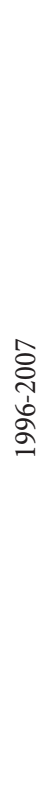 } & \multirow{2}{*}{\multicolumn{2}{|c|}{ 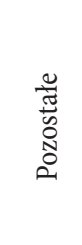 }} & 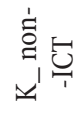 & $\stackrel{\text { If }}{0}$ & $\begin{array}{l}0 \\
\text { ñ. } \\
0\end{array}$ & $\stackrel{\mathscr{P}}{0}$ & $\begin{array}{l}\text { m } \\
\text { î }\end{array}$ & $\begin{array}{l}\stackrel{7}{\widetilde{O}} \\
\text { - }\end{array}$ & 8 & तै & $\begin{array}{l}0 \\
0 \\
0\end{array}$ & $\begin{array}{l}\infty \\
0 \\
0\end{array}$ & $\begin{array}{l}\text { If } \\
\text { o }\end{array}$ & $\stackrel{\infty}{\stackrel{\sim}{\sim}}$ \\
\hline & & & $\stackrel{\cup}{\cup}$ & ri & $\begin{array}{l}\frac{10}{0} \\
0\end{array}$ & $\begin{array}{l}\overrightarrow{0} \\
0 \\
0\end{array}$ & $\tilde{m}$ & $\underset{\text { J }}{\mathbb{Z}}$ & $\stackrel{\stackrel{2}{7}}{\tilde{\sigma}}$ & ָ̊ & $\vec{n}$ & $\stackrel{0}{n}$ & $\begin{array}{l}0 \\
\text { ñ }\end{array}$ & $\begin{array}{l}0 \\
\text { ñ. } \\
0\end{array}$ \\
\hline & \multirow{3}{*}{ 畓 } & 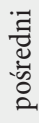 & $\begin{array}{l}\dot{\Xi} \\
\stackrel{\Xi}{\leftrightarrows} \\
\text { 它 }\end{array}$ & $\begin{array}{l}\infty \\
\sigma\end{array}$ & हैं & $\underset{-1}{8}$ & $\begin{array}{l}\text { t' } \\
\text { O }\end{array}$ & $\stackrel{\sim}{\stackrel{\sim}{\sim}}$ & $\underset{-1}{8}$ & $\begin{array}{l}\stackrel{2}{1} \\
0 \\
1\end{array}$ & $\begin{array}{l}\infty \\
0 \\
0\end{array}$ & $\frac{10}{0}$ & $\begin{array}{l}20 \\
\infty \\
0 \\
0\end{array}$ & $\underset{\sim}{\mathbb{\sigma}}$ \\
\hline & & \multirow{2}{*}{ 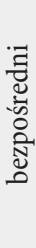 } & $\begin{array}{l}\breve{v} \\
\mathfrak{V}^{\prime}\end{array}$ & $\begin{array}{l}\text { 응 } \\
\text { - }\end{array}$ & oे & $\stackrel{2}{0}$ & $\begin{array}{l}\frac{12}{0} \\
0\end{array}$ & $\begin{array}{l}\stackrel{0}{0} \\
\stackrel{0}{0}\end{array}$ & $\begin{array}{l}\infty \\
0 \\
0\end{array}$ & $\stackrel{0}{0}$ & $\begin{array}{l}\overrightarrow{\widetilde{\sigma}} \\
\text { - }\end{array}$ & $\begin{array}{l}\text { İ } \\
\text { ó }\end{array}$ & $\stackrel{a}{0}$ & $\begin{array}{l}\frac{10}{0} \\
\stackrel{0}{0}\end{array}$ \\
\hline & & & 点 它 & $\overline{0}$ & $\begin{array}{l}0 \\
0 \\
0\end{array}$ & 운 & $\stackrel{\stackrel{2}{n}}{0}$ & ̊. & $\tilde{\tilde{\sigma}}$ & $\begin{array}{l}0 \\
0 \\
0\end{array}$ & $\begin{array}{l}\hat{\sigma} \\
\text { ó }\end{array}$ & $\begin{array}{l}\text { hn } \\
\text { nू }\end{array}$ & $\begin{array}{l}\widehat{\jmath} \\
\tilde{\sigma}\end{array}$ & $\stackrel{\text { }}{\tilde{\sigma}}$ \\
\hline & \multicolumn{3}{|c|}{ 品 } & $\hat{\sigma}$ & $\vec{m}$ & $\stackrel{\infty}{\infty}$ & $\hat{0}$ & $\begin{array}{l}\text { ָㅁ } \\
\text { i }\end{array}$ & $\stackrel{n}{\stackrel{n}{n}}$ & 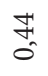 & $\underset{\sigma}{\tilde{\sigma}}$ & $\begin{array}{l}8 \\
i \\
i\end{array}$ & $\stackrel{2}{2}$ & 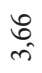 \\
\hline & \multicolumn{3}{|c|}{ 芴 } & 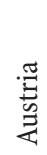 & $\frac{\overrightarrow{b 0}}{\ddot{D}}$ & 莺 & 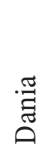 & 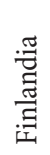 & 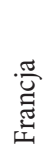 & $\begin{array}{l}\widehat{\hat{\mathrm{V}}} \\
\frac{\mathrm{o}}{3} \\
\overrightarrow{3}\end{array}$ & 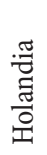 & $\begin{array}{l}\text { 苟 } \\
\text { 岕 } \\
\tilde{\omega}\end{array}$ & 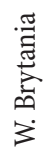 & $\widehat{\widehat{U}}$ \\
\hline
\end{tabular}




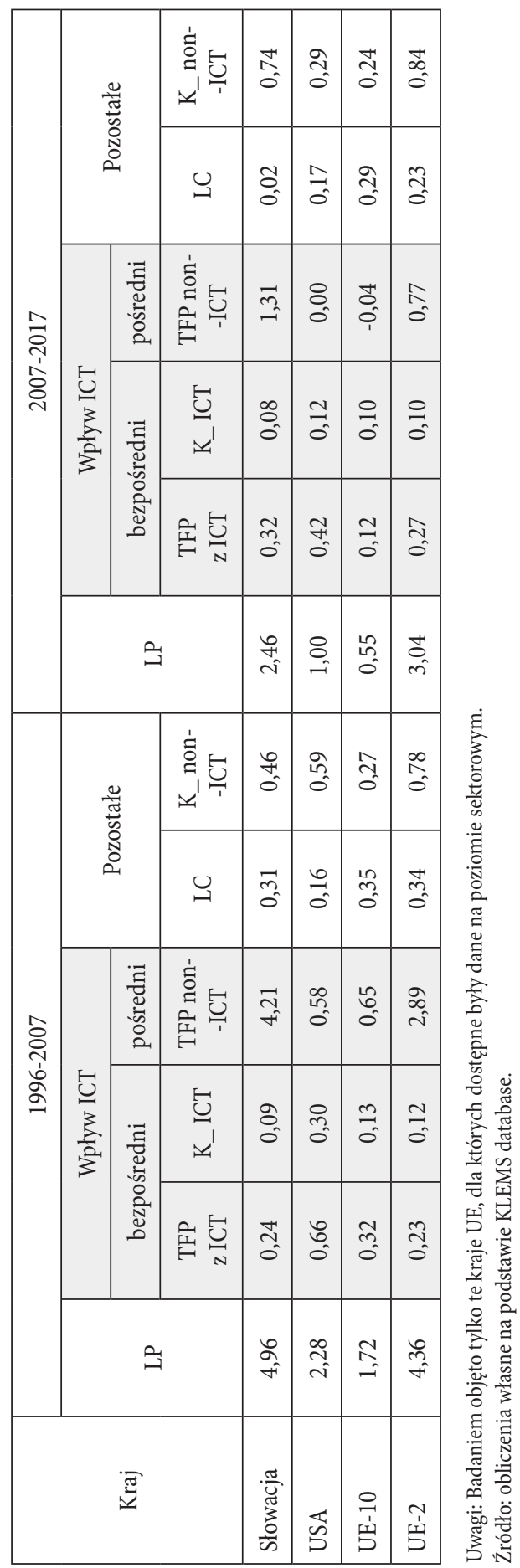


W okresie 1996-2007 w przypadku USA 0,96 p.p. z 2,3\% średniorocznego wzrostu produktywności pracy wynikało z bezpośredniego wpływu sektora ICT (wzrostu TFP w sektorze ICT oraz akumulacji kapitału ICT w innych branżach gospodarki). Podobną kontrybucję wśród badanych krajów UE obserwowano jedynie w Finlandii. Ogólnie rzecz biorąc, kontrybucja ta w grupie UE-10 była znacznie niższa i wynosiła 0,45 p.p., a Czechach i Słowacji - 0,35 p.p. W krajach UE zauważalny był jednak nieco wyższy pośredni wpływ sektora ICT na wzrost produktywności, związany ze wzrostem TFP w sektorach innych niż ICT (na skutek pojawienia się efektów spillover). Na efekty te w grupie UE-10 przypadało 0,65 p.p., a w USA - 0,58 p.p. W Czechach i na Słowacji wzrost TFP niemalże w całości był związany z pośrednim oddziaływaniem sektora ICT (2,89 p.p.).

W okresie 2007-2017 w przeciwieństwie do UE rola bezpośrednich kanałów oddziaływania sektora ICT na dynamikę produktywności pracy w USA jeszcze wzrosła (kontrybucja wynosiła 0,52 p.p. przy 1\% średniorocznym wzroście produktywności). Co ciekawe, w przypadku USA nie obserwowano pośredniego wpływu ICT. W krajach grupy UE-10 wpływ bezpośrednich efektów ICT oszacowano na 0,22 p.p. Jednocześnie miała miejsce ujemna kontrybucja efektów pośrednich. W sektorach użytkujących ICT (przynajmniej w części krajów tej grupy) obserwowano spadek TFP. Porównując kraje reprezentujące grupę „nowych” krajów członkowskich, można stwierdzić, że w Czechach i na Słowacji obserwowano pozytywny wpływ efektów spillover na TFP ( 0,77 p.p.) oraz istotniejsze niż w krajach UE-10 znaczenie efektów bezpośrednich (0,37 p.p.).

\section{Wnioski}

Wyniki badania przeprowadzonego w niniejszym artykule potwierdzają słuszność hipotezy o związku między rozwojem sektora ICT oraz luką produktywności pracy między UE i USA, przy czym zależność ta okazuje się być bardziej istotna w kontekście tzw. „starych” krajów członkowskich. „Nowe” kraje członkowskie o relatywnie niskim poziomie produktywności wykazywały w obu analizowanych okresach jej wysoką dynamikę, przy czym źródłem owego procesu „doganiania” (zarówno pozostałych krajów UE, jak i USA) były raczej tradycyjne czynniki wzrostu, tj. akumulacja kapitału ludzkiego oraz kapitału spoza sektora ICT. Analiza danych dla Słowacji i Czech dostarczyła jednak dowodów, że w krajach tej grupy istotną rolę w kształtowaniu dynamiki produktywności odgrywały (i mogą odgrywać w przyszłości) efekty pośrednie rozwoju sektora ICT w postaci wzrostu TFP $\mathrm{w}$ innych sektorach gospodarki. 
Różnicę dynamiki produktywności pracy między USA i krajami grupy UE-15 w okresie 1996-2017 można ściśle wiązać z dysproporcją obu regionów w zakresie ujawniania się bezpośrednich efektów rozwoju sektora ICT. USA wykazywały bowiem znacznie wyższą dynamiką TFP w tym sektorze oraz inwestycji w ICT niż większość krajów UE-15 (wyjątek stanowiło kilka krajów, głównie skandynawskich). Dysproporcje te pogłębiły się jeszcze w latach 2007-2017. W okresie tym dodatkowo zaobserwowano brak pośrednich efektów rozwoju sektorów ICT w krajach europejskich. Okazuje się, że w kraje grupy UE-15 miały trudności w generowaniu efektów spillover, a tym samym w uzyskiwaniu wymiernych korzyści $z$ inwestycji w ICT w postaci dodatkowego wzrostu TFP. Przyczyn takiego stanu rzeczy można upatrywać m.in. w relatywnie niskim poziomie tychże inwestycji (zwłaszcza w przełomowe technologie typu sztuczna inteligencja czy Internet rzeczy), np. w sektorze usług, oraz w zbyt wysokim stopniu regulacji europejskiego rynku towarów i rynku pracy, mogących utrudniać efektywną dyfuzję technologii.

Należy mieć świadomość pewnych ograniczeń zastosowanej metody badawczej, która pozwoliła jedynie na wstępną analizę pośrednich efektów ICT. W kolejnym etapie badań warto zastosować metody ekonometryczne, wprowadzając do modelu dodatkowe zmienne aproksymujące wspomniane efekty spillover. Więcej światła na omawiane kwestie może rzucić także rozszerzenie analiz na poziomie sektorowym.

\section{Bibliografia}

Arendt, Ł. (2016). Paradoks Solowa i determinanty wdrożenia technologii informacyjnych i telekomunikacyjnych. Gospodarka Narodowa, 281(1), 29-53.

Atkinson, R. D. (2008). How ICT Can Restore Lagging European Productivity Growth? Information Technology \& Innovation Foundation. Pobrano z: https://ssrn.com/ abstract $=3324656(24.04 .2020)$.

Atkinson, R.D. (2018). How ICT Can Restore Lagging European Productivity Growth? Information Technology \& Innovation Foundation. Pobrano z: https://espas. secure.europarl.europa.eu/orbis/sites/default/files/generated/document/ en/2018-ict-eu-productivity-growth.pdf (18.04.2020).

Biagi, F. (2013). ICT and Productivity: A Review of the Literature. Institute for Prospective Technological Studies Digital Economy Working Paper, 9. Pobrano z: http://dx.doi. org/10.2788/32940 (24.04.2020).

Bresnahan, T. F., Trajtenberg, J. E. (1995). General Purpose Technologies: Engines of Growth? Journal of Econometrics, 65(Special Issue, January), 83-108. 
Corry, D., Valero, A., van Reenen, J. (2011). UK Economic Performance since 1997: Growth, Productivity and Jobs. LSE Research Online Documents on Economics, 47521. Pobrano z: http://ideas.repec.org/p/ner/lselon/http--eprints.lse.ac.uk-47521-. html (27.04.2020).

Cygler, J. (2003). Program działań proinwestycyjnych dla sektora ICT w Polsce - wnioski z raportu. W: M. Górzyński, R. Woodward (red.), Innowacyjność polskiej gospodarki (s. 48-50). Warszawa: CASE.

Daveri, F. (2000). Is growth an Information Technology Story in Europe too?. University of Parma and IGIER. Pobrano z: http://web.econ.ku.dk/epru/files/wp/00-12. $\operatorname{pdf}(24.04 .2020)$.

Daveri, F. (2002). The new economy in Europe, 1992-2001. Oxford Review of Economic Policy, 18, 345-362.

Daveri, F. (2004). Why is there a productivity problem in Europe?, CEPS Working Document, 205. Pobrano z: https://www.files.ethz.ch/isn/29461/205_Why\%20 is\%20there.pdf (22.04.2020).

Gordon, R .J. (2002). Technology and Economic Performance in American Economy. NBER Working Paper, 8771, 1-59.

GUS. (2015). Społeczeństwo informacyjne w Polsce. Wyniki badań statystycznych z lat 2011-2015. Informacje i Opracowania Statystyczne. Warszawa: GUS.

Jorgenson, D. W. (1963). Capital Theory and Investment Behavior. American Economic Review, 53(2), 247-259.

Jorgenson, D. W., Griliches, Z. (1967). The explanation of Productivity Change. Review of Economic Studies, 34, 249-83.

Kotlewski, B., Błażej, M. (2016). Metodologia rachunku produktywności KLEMS i jego implementacja w warunkach polskich. Wiadomości Statystyczne, 9 (664), 86-108.

OECD. (2012). Measuring the Internet Economy: a Contribution to the Research Agenda. Paris: OECD.

OECD. (2019). Digitalisation and productivity: a story of complementarities. OECD Economic Outlook, 2019 (1). Paris: OECD. Pobrano z: https://www.oecd.org/economy/ growth/digitalisation-productivity-and-inclusiveness/ (02.05.2020).

Oulton, N. (2010). Long term implications of the ICT revolution: applying the lessons of growth theory and growth accounting. Centre for Economic Performance Discussion Papers, 1027. Pobrano z: http://eprints.lse.ac.uk/49303/1/dp1027.pdf (22.04.2020).

Pilat, D., Lee, F. (2001). Productivity Growth in ICT producing and ICT-using Industries: A Source of Growth Differentials in the OECD? OECD Science, Technology, and Industry Working Papers, 4. doi: 10.1787/7745763001210ECD 
Roeger, W. (2001). The Contribution of Information and Communication Technologies to Growth in Europe and the US: A Macroeconomic Analysis. European Economy. Economic Papers 2008-2015, 147. Pobrano z: https://ec.europa.eu/economy_finance/publications/pages/publication11060_en.pdf (04.05.2020).

Schreyer, P. (2000). The Contribution of Information and Communication Technology to Output Growth: A Study of the G7 Countries. OECD Science, Technology and Industry Working Papers, 2, 1-23. doi: 10.1787/151634666253

Solow, R. M. (1957). Technical change and the aggregate production function. The Review of Economics and Statistics, 39(3), 312-320.

Strauss, H., Samkharadze, B. (2011). ICT capital and productivity growth, EIB Papers, 16(2), 8-28.

Swan, T. W. (1956). Economic Growth and Capital Accumulation, Economic Record, 32(2), 334-361.

Timmer, M. P., van Ark, B. (2005). Does information and Communications technology drive EU-US productivity growth differentials? Oxford Economic Papers, 57, 693-716. doi: 10.1093/oep/gpi032

Van Ark, B. (2000). Measuring Productivity in the "New Economy": Towards a European Perspective". De Economist, 148 (1), 87-105.

Van Ark, B. (2016). The Productivity Paradox of the New Digital Economy, International Productivity Monitor, 31, 3-18.

Van Ark, B., Inklaar, R., McGuckin, R. H. (2003). Changing gear productivity, ICT and services: Europe and the United States. W: J .F. Christensen, P. Maskell (Eds.). The Industrial Dynamics Of The New Digital Economy (s. 56-99), Cheltenham: Edward Elgar Publishers.

Van Ark, B., O'Mahony, M., Timmer, M. P. (2008). The Productivity Gap between Europe and the United States: Trends and Causes. Journal of Economic Perspectives, 22(1), 25-44.

Van Welsum, D., Overmeer ,W., van Ark, B. (2013). Unlocking the ICT Growth Potential in Europe: Enabling People and Businesses. European Commission Digital Agenda for Europe, Bruksela.

WIIW. (2019). Industry Level Growth and Productivity Data with Special Focus on Intangible Assets. Report on methodologies and data construction for the EU KLEMS Release 2019.Vienna: The Vienna Institute for International Economic Studies. Pobrano z: https://euklems.eu/wp- content/uploads/2019/10/ Methodology.pdf (04.05.2020). 


\section{Streszczenie}

Celem artykułu jest weryfikacja hipotezy o istotnym związku między rozwojem sektora ICT a luką produktywności pracy między UE i USA w okresie 1996-2017. Analizę wpływu ICT na różnice w produktywności pracy przeprowadza się na poziomie makroekonomicznym i sektorowym, wykorzystując rachunek produktywności KLEMS. W świetle otrzymanych wyników różnicę dynamiki produktywności między USA i krajami UE (w szczególności tzw. starymi krajami członkowskimi) w analizowanym okresie można ściśle wiązać $\mathrm{z}$ dysproporcją obu regionów w zakresie ujawniania się bezpośrednich efektów rozwoju sektora ICT, tj. wzrostu TFP w tym sektorze oraz inwestycji w technologie informacyjno-komunikacyjne w pozostałych. Dysproporcje te pogłębiły się w okresie 2007-2017, kiedy zaobserwowano dodatkowo brak pośredniego wpływu ICT na produktywność pracy w europejskich gospodarkach (brak dodatkowego wzrostu TFP w innych sektorach).

SŁOWA KLUCZOWE: luka produktywności UE-USA, technologie informacyjno-komunikacyjne (ICT), łączna produktywność czynników produkcji (TFP), rachunek produktywności KLEMS.

\section{Summary}

The aim of the article is to verify the hypothesis about the significant relationship between the ICT sector development and the EU-US productivity gap in the period 1996-2017. The analysis of the ICT impact on productivity differences is carried out using the KLEMS productivity accounts at the macroeconomic and sectoral level. In the light of the obtained results, the difference in labour productivity dynamics between the US and the EU (in particular its so-called old member states) in the analysed period can be closely associated with the disproportion of both regions in the area of revealing the direct effects of ICT sector development, i.e. TFP growth in this sector and ICT investment in others. These disproportions deepened in the period 2007-2017, when the lack of ICT indirect impact on productivity (the lack of TFP growth in ICT-using sectors) in many European economies was additionally observed.

KEYwords: EU-US productivity gap, ICT, Total Factor Productivity, KLEMS productivity accounts.

\section{Nota o autorze}

Izabela Młynarzewska-Borowiec - dr, Uniwersytet Technologiczno-Humanistyczny w Radomiu, Wydział Ekonomii i Finansów; główne obszary działalności naukowej: ekonomia i finanse; e-mail: i.mlynarzewska@uthrad.pl; ORCID: 0000-0002-7852-554X. 